that "Business is the highest form of citizenship and advertising is the highest form of business". Does that view make for happiness, when a man is tired of his job, or for the altruism of good citizenship ? A superintendent of schools in the largest American city writes of showing a pupil how to be a radio announcer, or a baseball player. What will he do when the voice is gone, or the muscles for hard hitting are relaxed? There are many new jobs to-day, but one old one remains-the use of leisure time.

\section{Eduation in the United States}

Educatron has the name of being a dull, dismal subject, though it is incessantly concerned with youth, which is in the fine phrase of Pericles the spring of the world. Its exponents are full of its jargon and have not reached the last triumph of writing, which is simplicity. American work is usually too widely documented to be bright. So we welcome as an exception to this heaviness the October numbers of School Life, which comes from the U.S. Office of Education (monthly except August and September, 1 dollar a year), and School and Society, which is run by the Society for the Advaneement of Education (15 cents a copy). Both have a direct touch with the busy world scarcely possible in Great Britain, where there is less interest in vocational education; in the United States it leads to leaflets on poultry as well as on Soviet ideas of instruction. School Life includes a letter from the President indicating that it is a patriotic duty to continue normal education, unless required for special war work. Looking ahead, one might say that it is the business of education everywhere to prevent, if possible, the occurrence of another war. An ingenious graph arranged in ascending rows like a typewriter shows with commentary the increases and decreases in various grades of school attendance. "Radio in Schools and Colleges" recognizes that it cannot, alone and unajded, do much more than stimulate. There are no short cuts to learning, except in the optimistic promises of the world of advertisement. Teachers can learn more than pupils, but among the 360 colleges offering radio courses only one in twenty is designed for them.

There are good, long articles in School and Society on up-to-date ideas of the educated man, the prospects of education for war, with the mistakes of the past, on which, we note, all are not agreed, and the world the high school has to face to-day. A letter on "The Teacher's Professional Life" suggests that he should attend conventions, where he can exchange views about his 'shop'. It is important also that he should not confine himself to going about with other teachers and lose touch with the rapidly changing world which supplies his pupils and challenges him to produce good results for democracy. A plea for a better vocabulary among college seniors is interest. ing. But a "planned, concerted drive" may be less effective than good example, which leads to a tradition of using language carefully and well. A mark of the good speaker is his choice of adjectives.

\section{British Electrical and Allied Industries Research} Association

THE twentieth annual general meeting of this Association was held on February 14, when the annual report was presented. In a foreword written by the chairman of the council, Mr. C. W. Marshall, of the Central Electricity Board, many interesting remarks about research are made. He points out that research is rarely spectacular to the layman; but owing to the steadily increasing importance to the industry of the activities of the E.R.A., it is now widely appreciated. Mr. Marshall said he has followed the development of the Association from its inception, especially in its relation to electricity supply. Three classes of investigation pursued in the Association's laboratories and elsewhere have been of special interest to him because of their vital importance to the electrical welfare of Great Britain : these are the investigations into circuit-making and breaking, surge phenomena, and properties of insulation.

The search for the most effective and economical types of circuit-breaker has been one of the most difficult and interesting investigations in the history of electrical engineering. To-day, the essential basic phenomena are well understood, at least by switchgear specialists, and circuit-breakers which are to all intents and purposes free from the formerly dreaded fire and explosion risks are available for all applications. The E.R.A. has played a leading part in this development. Lightning research has been a less urgent matter because of the comparatively small incidence of lightning faults in Great Britain. It was nevertheless appreciated that these faults had to be eliminated, and a systematic scheme of investigation was drawn up several years ago. An important stage of the work will be marked by the publication in due course of an E.R.A. compendium of information on surge phenomena, and by the introduction of a commercial model of the E.R.A. surge filter for protecting electrical equipment against damage from lightning. E.R.A. investigations into the properties of electrical insulating materials are helping to make the fundamental discoveries of atomic physicists available to the practical electrical engineer.

\section{Rocket Flight to the Moon}

Condirions of life on this earth may turn the thoughts of the escapist to contemplation of other heavenly bodies. For nearness, the moon has much to commend it. The problem of the means of trans. port still remains. If rocket flight be chosen, J. W. Campbell's recent paper (Philosophical Magazine, January 1941) will be found to give considerable help. Special attention is given to the type of flight in which the observer moves with a massive body from which rockets are fired at intervals in directions suitably controlled to guide the main body. Assuming an initial velocity more than twice that of the present muzzle velocity of artillery shells (2500 ft./sec.), a calculation is made of the minimum mass of the moving "rocket ship". The result is $2 \times 10^{-9}$ of the earth's mass. If the mass were distributed as a homogeneous sphere of material of density about 